Volume 2, Nomor 1, Oktober 2020, pp 89-108. Copyright (C) 2019 JAFTA, Program Studi Magister Akuntansi, Fakultas Ekonomi, Universitas Kristen Maranatha. ISSN: 2654-4636 | E-ISSN: 2656-758X https://journal.maranatha.edu/index.php/jafta

\title{
Relevansi Nilai dan Determinan Pengungkapan Modal Intelektual
}

\author{
Oleh: \\ Rinto Hamonangan \\ Institut Bisnis dan Informatika Kwik Kian Gie \\ email: rintopanggabean@gmail.com \\ Carmel Meiden \\ Institut Bisnis dan Informatika Kwik Kian Gie \\ email: remon.gunanta123@gmail.com
}

\begin{abstract}
ABSTRAK
Beberapa dekade terakhir laporan keuangan tradisional mulai kehilangan relevansi nilai dari laba dan nilaibuku ekuitas. Modal intelektual adalah informasi penting yang merupakan sumber potensial pada perusahaan untuk mendapatkan keunggulan kompetitif yang sulit ditiru oleh pesaingnya serta mendorong perkembangan dan kesuksesan bisnis di masa depan. Penelitian ini bertujuan untuk menguji relevansi nilai pengungkapan modal intelektual pada perusahaan berjenis industri tradisional dan juga non-tradisional, serta menguji faktor-faktor apa saja yang mempengaruhi perusahaan untuk mengungkapkan modal intelektual.

Dengan menggunakan metode purposive judgement sampling, sampel perusahaan terdiri dari 68 perusahaan dari beragam jenis industri yang terdaftar di Bursa Efek Indonesia pada tahun 2014-2018. Untuk pengujian hipotesis menggunakan analisis regresi linear berganda. Hasil penelitian menunjukkan bahwa pengungkapan modal intelektual memiliki relevansi nilai pada perusahaan tradisional, namun pada perusahaan non-tradisional tidak terbukti bahwa pengungkapan modal intelektual memiliki relevansi nilai. Umur perusahaan, kualitas audit, market book ratio, ukuran perusahaan, dan tipe industri memiliki pengaruh terhadap pengungkapan modal intelektual, sedangkan leverage dan profitabilitas tidak memiliki pengaruh terhadap pengungkapan modal intelektual.
\end{abstract}

Kata kunci: Relevansi nilai, modal intelektual, umur perusahaan, industri tradisional, industri non-tradisional

\section{ABSTRACT}

In recent decades users have emphasized that traditional financial reporting is beginning to lose the relevance of the value of earnings and the book value of equity. To cover these weaknesses, investors began to look for other information to make investment decisions. Intellectual capital is included in the top ten in the information needed by information users. Intellectual capital is a potential source for modern companies to gain competitive advantages that are difficult for competitors to imitate and drive business development and success in the future. This study aims to examine the value relevance of disclosure of intellectual capital information on traditional industrial and non-traditional companies, and examine what factors influence companies to disclose intellectual capital.

Using the purposive judgment sampling method, the company sample consisted of 68 companies from various types of industries that were listed on the Indonesia Stock Exchange in 2014-2018. The results is disclosure of intellectual capital has value relevance in traditional companies, but in non-traditional companies there is not enough evidence found 
that disclosure of intellectual capital has value relevance. Company age, audit quality, market book ratio, company size, and type of industry have a strong influence on intellectual capital disclosure. Whereas leverage and profitability have no influence on intellectual capital disclosure.

Keywords: Intellectual capital, intellectual capital disclosure, firm age, traditional industry, non-traditional industry

\section{PENDAHULUAN}

Tujuan umum laporan keuangan dalam Conceptual Framework for Financial Reporting yang dikeluarkan oleh IASB (2018) adalah untuk memberikan informasi keuangan yang berguna bagi pengguna dalam mengambil keputusan berkaitan dengan penyediaan sumber daya untuk entitas. Keputusan pengguna yaitu bagi investor keputusan tentang membeli, menjual, atau menahan instrumen ekuitas seperti saham. Agar dapat bermanfaat suatu laporan keuangan harus memiliki karakteristik kualitatif yaitu relevan (relevance) dan faithfull representation. Informasi dapat dikatakan relevan apabila mampu mempengaruhi/merubah pengambilan keputusan.

Penelitian tentang relevansi nilai sudah dilakukan sejak lama. Salah satunya menurut Ball and Brown (1968) salah satu informasi yang paling mempengaruhi investor dalam mengambil keputusan investasi adalah laba perusahaan. Harga saham tersebut berubah ketika karena informasi direspon oleh para investor. Laba kejutan (unexpected return) dapat mempengaruhi besarnya return yang diterima oleh investor, penurunan dan peningkatan laba berhubungan dengan penurunan atau kenaikan harga saham.

Kurang lebih dalam bebrapa dekade terakhir para peneliti, lembaga akuntansi dan pengguna profesional menekankan bahwa pelaporan keuangan tradisional tidak memiliki kemampuan untuk menangkap informasi pada modal intelektual (Francis et $a l .$, 1999). Dengan adanya peningkatan ketidakpuasan pelaporan keuangan menandakan bahwa laporan keuangan kehilangan relevansinya dalam melaporkan dan menggambarkan kinerja perusahaan.

Bozzolan et al (2003) lebih lanjut menyatakan bahwa terjadi peningkatan ketidakpuasan atas pelaporan keuangan tradisional dan kemampuan menyediakan ketercukupan informasi bagi pemegang kepentingan untuk menciptakan kemakmuran. Pelaporan keuangan tradisional tidak secara khusus mempertimbangkan informasi pengungkapan Intellectual Capital (IC) yang merupakan persentase yang signifikan dari nilai perusahaan (Guthrie et al, 2006) Dalam sistem akuntansi, modal intelektual termasuk dalam intangible asset. Namun 
tidak dapat dicantumkan dalam neraca, karena modal intelektual dianggap sebagai bentuk unaccounted capital. Akibatnya, munculnya kesenjangan informasi karena informasi yang tersedia tidak cukup bagi stakeholders dan juga kurangnya informasi menyebabkan hambatan utama bagi pengakuan pentingnya modal intelektual.

Informasi tentang modal intelektual termasukke dalam sepuluh besar informasi yang dibutuhkan oleh pengguna informasi (Taylor and Associate, dalam Williams, 2001). Price Waterhouse Coopers melakukan survey terhadap organisasiorganisasi untuk mengetahui tipe kebutuhan informasi investor (Eccles et al, 2011). Di antara sepuluh tipe informasi hanya tiga yang merupakan tipe informasi keuangan (cash flow, earnings, gross margin) dan sisanya yaitu tujuh yang terdiri dari data internal perusahaan (strategic direction dan competitive landscape) dan lima tipe lainnya yang dipertimbangkan adalah intangible (market growth, quality/experience of the management team, market size and market share, speed to market). Dari survey tersebut tipe informasi yang dipertimbangkan oleh investor lebih banyak masuk dalam komponen modal intelektual. Namun pada kenyataannya tipe informasi ini tidak diungkapkan oleh manajer, dan hal ini menyebabkan adanya “information gap" (Bozzolan et al, 2003).
Dalam studi perbandingan yang lebih luas antara industri non-tradisional dan tradisional, Francis dan Schipper (1999) menguji apakah relevansi nilai perusahaan yang terdaftar di sektor teknologi tinggi telah menurun dari waktu ke waktu dibandingkan dengan perusahaan tradisional. Mereka memasukkan semua perusahaan dalam industri komputer, elektronik, farmasi dan telekomunikasi dalam sampel non-tradisional, dan perusahaan dari pertanian, konstruksi, transportasi udara dan kereta api dalam sampel tradisional. Mereka memberikan bukti marginal yang mendukung klaim yang dimiliki perusahaan non- tradisional mengalami penurunan yang lebih besar dalam relevansi nilai laba dan jumlah ekuitas daripada perusahaan teknologi yang lebih rendah.

Peneliti tertarik untuk menggunakan pendekatan pada perusahaan pada nontradisional seperti : perusahaan energi, farmasi, jasa komputer dan perangkatnya, elekronika, kabel, telekomunikasi dan utilitas. Selanjutnya pada perusahaan tradisional seperti perkebunan, otomotif dan komponen, semen, pulp dan kertas, konstruksi non bangunan, sub sektor kayu dan pengolahannya dan juga jalan tol, otomotif, pelabuhan, bandara dan sejenisnya yang terdaftar di Bursa Efek Indonesia. Alasannya karena sektor tersebut merupakan salah satu penopang 
pembangunan ekonomi suatu negara meskipun berbasis industri tradisional, dan juga perusahaan pada kelompok nontradisional memiliki karakteristik berbasiskan pada pengetahuan, dimana perusahaan jenis ini tidak hanya bertumpu pada sumber daya yang bersifat fisik namun juga bersifat pengetahuan. (Firer et al., 2003).

Pada penelitian sebelumnya diketahui bahwa pengungkapan modal intelektual berpengaruh positif terhadap nilai perusahaan dan kinerja keuangan perusahaan (Alfraih, 2018; Rachmawati, 2018; Garanina., 2017, Vafaei, 2011, Abdolmohammadi, 2005). Dalam penelitian tersebut diungkapkan jika suatu perusahaan memiliki intellectual capital dengan efisiensi pada ketiga komponennya (capital employed efficiency, human capital efficiency, dan structural capital efficiency), maka perusahaan tersebut akan memiliki market value dan financial performace yang meingkat terus menerus dari tahun ke tahun. Hal yang sama dikemukakan oleh Vafaei (2011) yang mengungkapkan bahwa ICD secara positif terkait dengan harga pasar (memiliki relevansi nilai) di perusahaan di dua dari empat negara dan dalam industri non-tradisional.

Hasil ini tidak sejalan dengan hasil penelitian Firrer dan Williams (2003) yang menyatakan bahwa tidak ada pengaruh antara intellectual capital dengan market value. Selain itu, investor di Indonesia cenderung tidak memperhatikan atau menganalisis secara fundamental tetapi biasanya secara teknikal, artinya investor akan melihat perkembangan harga saham perusahaan dari watu ke waktu

Amir dan Lev (1996) menguji relevansi nilai akuntansi keuangan dan informasi non-keuangan dalam industri telekomunikasi. Mereka mengidentifikasi fakta bahwa industri ini banyak berinvestasi dalam penelitian dan pengembangan, penciptaan basis pelanggan, pengembangan waralaba dan merek, tetapi sepenuhnya mengeluarkan investasi tersebut dalam laporan keuangan. Sementara mereka tidak menemukan nilai relevansi informasi keuangan, dan informasi non-finansial menjadi relevan secara nilai dalam model regresi. Mereka menyimpulkan bahwa informasi non-keuangan memainkan peran "pelengkap" dalam menjelaskan relevansi nilai.

Tujuan penelitian ini adalah untuk menganalisis dan mengetahui:

1. Apakah pengungkapan modal intelektual memiliki relevansi nilai di perusahaan tradisional dan non-tradisional? 
2. Apakah dengan menambahkan pengungkapan modal intelektual sebagai "informasi lain" dalam model Ohlson (1995) dapat meningkatkan kekuatan penjelas nilai pasarnya di industri tradisional dan nontradisional?

3. Faktor-faktor apa saja yang mempengaruhi pengungkapan modal intelektual?

\section{KAJIAN LITERATUR DAN PENGEMBANGAN HIPOTESIS}

Informasi akuntansi harus mampu membuat perbedaan dalam sebuah keputusan. Apabila informasi tersebut tidak dapat mnegubah keputusan, maka informasi tersebut dapat dikatakan tidak relevan. Informasi yang relevan akan membatu untuk memprediksi masa lalu, kini dan masa depan atau dapat dikatakan nilai prediktif. Informasi yang relevan juga membantu pemakai menjustifikasi atau mengoreksi ekspektasi atau harapan masa lalu, atau dikatakan nilai umpan balik. Agar relevan, informasi juga harus tersedia kepada pengambil keputusan sebelum informasi tersebut kehilangan kapasitas untuk mempengaruhi keputusan yang diambil.

Laporan keuangan berkembang sesuai dengan tuntutan stakeholder terhadap informasi tentang perusahaan. Pada awalnya perusahaan hanya menyajian laporan keuangan dengan menampilkan indikator keuangan perusahaan karena .kebutuhan pengguna laporan keuangan terbatas pada pengambilan keputusan ekonomi yang mendasarkan pada informasi-informasi keuangan semata. Informasi-informasi mengenai pengelolaan perusahaan dilaporkan secara terpisah pada laporan manajemen guna melengkapi informasi laporan keuangan.

Francis dan Schipper menyelidiki relevansi informasi laporan keuangan kepada investor untuk tujuan penilaian dari waktu ke waktu dan menemukan bahwa relevansi nilai laba menurun sementara relevansi neraca dan book value information meningkat. Menurut resourced based theory pengidentifikasian sumber daya yang dimiliki perusahaan dapat menciptakan nilai tambah bagi perusahaan dalam mengambil kesempatan dan menghadapi ancaman sehingga perusahaan memiliki keunggulan kompetitif yang berbeda dengan perusahan lain, tidak mudah ditiru, dan tidak tergantikan.

Oleh karena itu, jika informasi yang terkandung dalam laporan keuangan tidak cukup untuk mengambil keputusan dan untuk memprediksi arus kas di masa depan, maka informasi modal intelektual tambahan diperlukan oleh investor dalam membuat keputusan harus meningkatkan penilaian perusahaan. Harapannya adalah tambahan 
informasi tersebut meningkatkan kekuatan penjelas dari nilai buku dan earnings untuk nilai pasar karena kesenjangan informasi antara investor dan perusahaan.

$$
\text { Pada penelitian sebelumnya }
$$
diketahui bahwa pengungkapan modal intelektual berpengaruh positif terhadap nilai perusahaan dan kinerja keuangan perusahaan (Alfraih, 2018; Rachmawati, 2018; Garanina., 2017, Vafaei, 2011, Abdolmohammadi, 2005). Vafaei (2011) menemukan bahwa pengungkapan modal intelektual memberikan efek pada relevansi nilai dari laba dan nilai buku ekuitas, dan menyimpulkan bahwa investor menggunakan pengungkapan modal intelektual untuk melengkapi analisis laporan keuangan. Oleh karena itu, jika informasi yang terkandung dalam laporan keuangan tidak mencukupi untuk keperluan penilaian, maka informasi pengungkan modal intelektual tambahan yang diungkapkan untuk membantu investor dalam pengambilan keputusan mereka. Harapannya informasi modal intelektual dapat meningkatkan kekuatan penjelas nilai buku ekuitas dan laba untuk nilai pasar karena kesenjangan informasi antara perusahaan dan investor berkurang.

H1a : Pengungkapan modal intelektual mempunyai pengaruh positif terhadap nilai perusahaan pada perusahaan dengan jenis industri tradisional.
H1b : Pengungkapan modal intelektual mempunyai pengaruh positif terhadap nilai perusahaan perusahaan dengan jenis industri non- tradisional.

H1c : Menambahkan pengungkapan modal intelektual sebagai "informasi lain" dalam model Ohlson (1995) meningkatkan kekuatan penjelas nilai pasarnya di industri tradisional

Ada banyak faktor yang diprediksi dapat mempengaruhi perusahaan dalam menambah informasi yang diberikan kepanda pengguna laporan, dalam hal ini adalah pengungkapan tentang modal intelektual. Salah satunya adalah umur perusahaan, biasanya perusahaan yang memiliki umur lebih muda memiliki insentif untuk melaporkan lebih banyak karena mengahadapi ketidakpastian yang lebih besar. Namun dilain sisi perusahaan yang berumur lebih tua atau sering juga disimpulkan sebagai perusahaan berputasi tinggi cenderung mengungkapkan lebih banyak. (Blanco, 2015) Umur perusahaan menunjukkan kemampuan perusahaan bersaing dan memanfaatkan peluang bisnis. Semakin lama umur perusahaan maka semakin berpengalaman dan terpercaya dalam penyajian dan pengungkapan informasi, termasuk dalam pengungkapan modal intelektual.

Berdasarkan pada teori kagenan dalam Ferreira (2012), auditing merupakan 
cara untuk mengurangi biaya keagenan dan meningkatkan kredibilitas dari informasi yang diungkapkan. Hal tersebut dapat mengurangi asimetri informasi yang antara principal dan agen, banyak penelitian yang menunjukan KAP yang berafiliasi dengan Big Four menyediakan secara realtif kualitas hasil audit yang lebih baik dibandingkan KAP yang tidak berafiliasi dengan Big Four. KAP yang berafiliasi dengan Big Four memiliki sumber daya yang lebih baik dibandingkan dengan KAP lainnya. Selain itu, untuk menjaga reputasinya maka KAP yang berafiliasi dengan Big Four tidak akan melakukan tindakan yang dapat merusak reputasinya dan meminta perusahaan untuk menyajikan laporan keuangan secara lebih detail. Oleh karena itu, perusahaan yang menghadapi biaya keagenan yang tinggi akan menggunakan jasa KAP yang berafiliasi dengan Big 4 (Ferreira et al., 2012). Hal tersebut tersebut sejalan dengan penelitian yang dilakukan oleh Woodcock and Whiting (2009) dan Ferreira (2012) yang menyatakan semakin baik kualitas audit maka informasi terkait modal intelektual yang diungkapkan akan semakin banyak.

Ukuran dari perusahaan audit - teori agensi menunjukkan bahwa pengawasan luar yang efektif mengurangi konflik di perusahaan dan memberikan perusahaan dengan insentif untuk menggunakan pengungkapan sukarela untuk mengkomunikasikan bahwa mereka bertindak dengan cara yang tepat (Watson et al., 2002). Karena auditor besar mengaudit banyak perusahaan, mereka lebih independen dari klien mereka dan memiliki pengaruh lebih tinggi pada praktik pengungkapan mereka (Barako et al., 2006). Khususnya, Perusahaan-perusahaan audit Big Four telah banyak mempromosikan gagasan orientasi investor dan modal intelektual. Sesuai dengan teori sinyal, diaudit oleh salah satu audit besar perusahaan dapat menandakan komitmen untuk transparansi yang lebih besar dan orientasi investor ke lokal serta investor internasional sebagai perusahaan audit ini beroperasi secara internasional (Alsaeed, 2006). Oleh karena itu, pengungkapan modal intelektual diharapkan berhubungan positif dengan ukuran perusahaan audit.

Perusahaan membutuhkan dana untuk membiayai peluang investasinya, perusahaan memiliki insentif untuk mengungkapkan lebih banyak untuk menegurangi biaya pendanaan eksternal. (Healy dan Palepu, 2001) Sehingga dapat dikatakan perusahaan yang memiliki leverage yang tinggi akan mengungkapkan infromasi modal intelektual lebih banyak. Baker dan Wurgler (2002) menggunakan market to book ratio untuk menguji Market Timing Theory guna melihat apakah saham perusahaan sedang mengalami overvalue atau undervalue. Jika market to book ratio 
tinggi artinya perusahaan sedang mengalami overvalue, sehingga perusahaan akan senantiasa menambah modal dengan jalan menerbitkan saham baru dan tingkat leverage akan rendah. Perusahaan yang memiliki market to book ratio yang rendah akan merusaha mengungkapkan informasi informasi tentang modal intelektual agar dapat meningkatkan valuasi dari harga saham.

Sesuai dengan signaling theory, perusahaan yang memiliki profibilitas tinggi akan mengungkapkan modal intelektual untuk mendekakan dengan perusahaan lain yang kurang menguntungkan. Selain itu, memlui sinyal tersebut bahwa perusahaan dapat menunjukan bahwa profitabilitas mungkin hasil dari investasi dalam modal intelektual dan perusahaan akan menggunakan pengungkapan modal intelektual untuk memberikan sinyal penggunaan yang signifikan dalam bentuk investasi tersebut (Li et al., 2008). Dengan demikian, semakin tinggi profitabilitas perusahaan maka perusahaan akan mengungkapkan lebih banyak informasi tentang modal intelektual.

Ukuran perusahaan berhubungan negatif dengan biaya pengungkapan dan risiko pengungkapan (Cormier et al., 2009). Biaya agensi lebih tinggi untuk perusahaan besar karena pemangku kepentingan lebih luas (Alsaeed, 2006). Juga, perusahaan yang lebih besar memiliki insentif yang lebih tinggi untuk menghindari hokum dan biaya politik yang meningkat dengan ukuran perusahaan . Selain itu, permintaan informasi dan kemungkinan pengawasan publik dan litigasi meningkat dengan ukuran perusahaan. Secara keseluruhan, perusahaan yang lebih besar menghadapi manfaat yang lebih tinggi dan biaya yang lebih rendah dari pengungkapan informasi tambahan secara sukarela (Brown dan Hillegeist, 2007).

Berdasarkan teori dan temuan peneliti sebelumnya, Bukh et al. (2005), Bozzolan (2003) dan Woodcock dan Whiting (2009) dapat disimpulkan bahwa perusahaan yang bernilai modal intelektual tinggi akan mengungkapkan informasi modal intelektualnya lebih banyak dibandingkan dengan perusahaan lainnya. Hal ini disebabkan bahwa perusahaan ingin menyampaikan kepemilikan modal intelektualnya dan untuk memberikan sinyak bagi investor atas kemampuan perusahaan yang sesungguhnya. Selain itu, permintaan terhadap pengungkapan modal intelektual juga besar terhadap perusahaan yang memiliki teknologi tinggi karena dipandang melakukan investasi dalam jumlah yang sangat besar dalam modal intelektual seperti sumber daya manusia, pengetahuan, brand, program untuk mempertahankan loyalitas pelanggan, dan lain sebagainya.

Sedangkan untuk meneliti determinan pengungkapan modal intelektual, 
berdasarkan landasan teori dan kerangka pemikiran model diatas, maka hipotesis penelitian adalah sebagai berikut :

H2a : Umur perusahaan berpengaruh terhadap pengungkapan modal intelektual

$\mathrm{H} 2 \mathrm{~b}$ : Kualitas audit berpengaruh positif terhadap pengungkapan modal intelektual

$\mathrm{H} 2 \mathrm{c}$ : Leverage berbasis saham berpengaruh positif terhadap pengungkapan modal intelektual

H1d : Nilai Perusahaan berpengaruh positif terhadap terhadap pengungkapan modal intelektual

H2e : Profitabilitas berpengaruh terhadap pengungkapan modal intelektual

H2f : Ukuran perusahaan berpengaruh positif terhadap pengungkapan modal intelektual

$\mathrm{H} 2 \mathrm{~g}$ : Tipe industri berpengaruh terhadap pengungkapan modal intelektual

\section{METODE PENELITIAN}

Berdasarkan purposive sampling dan uji outlier diperoleh sample final sebanyak 68 perusahaan, yang terdiri dari 25 pada industri non- tradisional dan 43 sampel pada industri tradisional selama periode 2014-2018 dengan menggunakan laporan tahunan sebagai sumber data pengungkapan modal intelektual.
Penelitian ini menggunakan indeks yang dikembangkan oleh Bukh et al. (2005) yang terdiri dari 78 item yang menggambarkan pengungkapan modal intelektual, dan menggunakan content analysis untuk mengukur jumlah pengungkapan modal intelektual dengan membaca dan memberi kode informasi yang terkandung di dalamnya menurut kerangka modal intelektual yang dipilih

Model untuk mengukur relevansi relatif yang dikembangkan Ohlson (1995), model 1 untuk menjelaskan relevansi nilai yang mencerminkan nilai kapitalisasi pasar perusahaan merupakan gambaran dari nilai buku ekuitas dan laba bersih perusahaan. Selanjutnya dalam model penelitian ini dengan memasukkan informasi tambahan untuk mengetahu relevansi nilai dari pengungkapan modal intelektual yang disediakan dari laporan tahunan perusahaan terhadap harga saham. Oleh karena itu skor ICD dimasukkan sebagai proksi langsung untuk informasi lain yang menangkap sejauh mana ICD memiliki relevansi nilai. Berikut penjabaran model 1:

$$
\mathrm{MVit}=\beta 0+\beta 1 \mathrm{BV} \text { it }-1+\beta 2 \mathrm{Eit}
$$

Model tersebut digunakan untuk menguji pengaruh nilai buku ekuitas dan laba terhadap nilai pasar perusahaan tanpa adanya informasi lain, kemudian selanjutnya dengan menambahkan "informasi lainnya" berupa pengungkapan modal intelektual 
untuk menguji apakah ICD dapat meningkatkan kekuatan penjelas nilai pasarnya di industri tradisional dan nontradisional.

$$
M V_{i t}=\beta 0+\beta 1 B V i t+\beta 2 E i t+\beta 3 I C D i t
$$

Dimana :

MVit : Harga saham terakhir pada periode $\mathrm{t}$

BVit : Nilai buku ekuitas pada periode $t$

ICD : Skor pengungkapan modal intelektual yang diukur dengan indeks Bukh (2005)

Model 2 adalah untuk mengetahui determinan yang mendorong perusahaan dalam memberikan informasi modal intelektual dengan menggunakan model berikut :

$\mathrm{ICD}_{\text {it }}=\beta_{0}+\beta_{1} \mathrm{AGE}+\beta_{2} \mathrm{AUDIT}+\beta_{3} \mathrm{LEV}+$ $\beta_{4} \mathrm{NP}+\beta_{5} \mathrm{PROF}+\beta_{6} \mathrm{SIZE}+\beta_{7} \mathrm{TYPE}$

Dimana :

ICD : Skor pengungkapan Intellectual Capital yang diukur dengan indeks

AGE : Umur perusahaan dimulai dari awal listing di Bursa Efek Indonesia

AUDIT : Kualitas audit yang diproksi menggunakan ukuran perusahaan auditor, nilai 1 jika perusahaan diaudit oleh Big Four, dan 0 jika sebaliknya

LEV : Leverage, diukur dengan Total Debt dibagi dengan Total Asset

NP : Nilai perusahaan diukur dengan market to book ratio

PROF : Profitabilitas, diukur dengan Net Profit Margin

SIZE : Ukuran Perusahaan, diukur dengan menggunakan Ln dari Total Asset

TYPE : Tipe industri, nilai 1 jika perusahaan berjenis non-tradisional, dan 0 jika perusahaan berjenis tradisional

\section{HASIL DAN PEMBAHASAN}

Hasil pengujian model 1 adalah untuk mengetahui relevansi nilai pengungkapan modal intelektual pada perusahaan tradisonal dan non- tradisonal, dapat dilihat dalam tabel berikut :

Tabel 1. Ringkasan Hasil Pengujian Relevansi Nilai Pada Perusahaan Tradisional

\begin{tabular}{|c|c|c|c|c|c|c|}
\hline \multirow{2}{*}{$\begin{array}{c}\text { Variabel } \\
\text { Independen }\end{array}$} & \multicolumn{3}{|c|}{ Sebelum ICD } & \multicolumn{3}{c|}{ Setelah ICD } \\
\cline { 2 - 7 } & Koe. beta & $\mathbf{t}$ & Sig & Koe. beta & $\mathbf{t}$ & Sig \\
\hline BV & 0,576 & 0,335 & 0,00 & 0,544 & 10,6 & 0.0 \\
\hline EPS & 0,273 & 10,72 & 0,00 & 0,229 & 4,47 & 0.0 \\
\hline ICD & & & & 0,23 & 5,27 & 0.0 \\
\hline Sig. F & \multicolumn{3}{|c|}{0,00} & \multicolumn{3}{c|}{0,00} \\
\hline R Square & \multicolumn{3}{|c|}{0,585} & \multicolumn{3}{c|}{0,628} \\
\hline Adj. R-Square & 0,581 & \multicolumn{3}{c}{} \\
\hline
\end{tabular}


Hasil pada tabel 1 meruapakan hasil uji relevansi nilai pada perusahaan tradisional. Pada uji $\mathrm{F}$ nilai signifikansi bernilai 0,000 lebih kecil daripada nilai $\alpha$ $(0,05)$ yang berarti bahwa model fit dan layak untuk dijadikan model penelitian. Bedasarkan hasil uji-T sebelum variabel ICD dimassukan kedalam model, nilai buku ekuitas dan laba per saham berpengaruh signifikan terhadap harga saham di pasar, ditunjukkan dari hasil sig. pada seluruh variabel independent $<0,05$. Kemudian setelah ICD dimasukkan ke dalam model, laba, nilai buku ekuitas dan pengungkapan modal intelektual berpengaruh signifikan terhadap harga saham di pasar, ditunjukkan dari hasil sig. pada seluruh variabel independent $<0,05$.

Nilai $R$ Square 0,585 dan 0,633 menunjukkan seberapa besar variabel independen dapat menjelaskan variabel dependen. Peneliti mencoba membandingkan $R$ square sebelum dan setelah menambah ICD untuk menguji ICD memiliki "explanatory power" sebagai informasi tambahan. Peningkatan nilai Rsquare $(58,5 \%<63,3 \%)$ menunjukkan bahwa kekuatan penjelas meningkat setelah
ICD dimasukkan sebagai "other information" kedalam model Ohlson (1995).

Berdasarkan hasil pengujian data yang dilakukan ditemukan bukti bahwa pada perusahaan yang berjenis industri tradisional pengungkapan modal intelektual memiliki relevansi nilai. Hal ini juga dapat disimpulkan bahwa pengungkapan modal intelektual memainkan peran sebagai pelengkap dalam menjelaskan relevansi nilai.

Pengungkapan modal intelektual berpengaruh positif terhadap nilai perusahaan dan kinerja keuangan perusahaan, hasil ini konsisten dengan penelitian terdahulu. (Alfraih, 2018; Rachmawati, 2018; Garanina., 2017, Vafaei, 2011,

Abdolmohammadi, 2005). Dalam penelitian tersebut diungkapkan jika suatu perusahaan memiliki intellectual capital dengan efisiensi pada ketiga komponennya (capital employed efficiency, human capital efficiency, dan structural capital efficiency), maka perusahaan tersebut akan memiliki market value dan financial performace yang meingkat terus menerus dari tahun ke tahun 
Tabel 2. Ringkasan Hasil Pengujian Relevansi Nilai Pada Perusahaan Non-Tradisional

\begin{tabular}{|c|c|c|c|c|c|c|}
\hline \multirow{2}{*}{$\begin{array}{c}\text { Variabel } \\
\text { Independen }\end{array}$} & \multicolumn{3}{|c|}{ Sebelum ICD } & \multicolumn{3}{|c|}{ Setelah ICD } \\
\hline & Koe. beta & $t$ & Sig & Koe. beta & $t$ & Sig \\
\hline BV & 0,329 & 3,732 & 0,00 & 0,323 & 3,69 & 0,00 \\
\hline EPS & 0,197 & 2,231 & 0,03 & 0,190 & 2,17 & 0,00 \\
\hline ICD & & & & 0,148 & 1,84 & 0,07 \\
\hline \multicolumn{2}{|c|}{ Sig. F } & \multicolumn{2}{|c|}{0,00} & \multicolumn{3}{|c|}{0,00} \\
\hline \multicolumn{2}{|c|}{ R Square } & \multicolumn{2}{|c|}{0,199} & \multicolumn{3}{|c|}{0,220} \\
\hline \multicolumn{2}{|c|}{ Adj. R-Square } & \multicolumn{2}{|c|}{0,185} & \multicolumn{3}{|c|}{0,201} \\
\hline
\end{tabular}

Selanjutnya dalam Tabel 2 sebelumnya oleh Vafaei (2001), pada menunjukkan relevansi nilai dari penelitian ini ditemukan bahwa pengungkapan modal intelektual pada pengungkapan modal intelektual tidak perusahaan non-tadisional. pada uji $\mathrm{F}$ nilai memiliki relevansi nilai, padahal perusahaan signifikansi bernilai 0,000 lebih kecil non-tradisional secara rata-rata lebih banyak daripada nilai $\alpha(0,05)$ yang berarti bahwa mengungkapkan informasi modal model fit dan layak untuk dijadikan model intelektual. Hal ini kemungkinan karena penelitian. Selanjutnya pada uji-T didapatkan hasil bahwa nilai buku dan laba per-saham memiliki pengaruh yang signifikan terhadap harga saham dipasar. Namun, setelah variabel ICD dimasukkan diketauhi bahwa pengungkapan modal intelektual tidak berpengaruh terhadap harga saham (sig. one-tiled 0,068 lebih besar dari nilai $\alpha 5 \%)$.

Pada hasil R-Square sebelum dimasukkan variabel ICD bernilai 0,199 dan setelah ditambahkan variabel ICD bertambah menjadi 0,220. Menunjukkan bahwa kekuatan penjelas meningkat setelah ICD dimasukkan sebagai "other information" kedalam model Ohlson (1995).

Pada perusahaan non-tradisional sejalan dengan penelitian yang dilakukan investor pada perusahaan non-tradisional di Indonesia cenderung tidak memperhatikan atau menganalisis secara fundamental melainkan secara teknikal, artinya investor membuat keputusan tentang investasi berdasarkan perkembangan harga saham dari waktu ke waktu. Hal tersebut dilihat dari perusahaan non-tradisional di Indonesia rata-rata diisi oleh perusahaan buku ketiga. Hasil tersebut menandakan tidak terdapat cukup butki bahwa informasi pengungkapan modal intelektual memiliki relevansi nilai di perusahaan nontradisional.

Dari hasil pada model 1 membuktikan adanya peningkatan RSquare, hal tersebut menandakan bahwa kekuatan penjelas meningkat setelaj 
pengungkapan modal intelektual dimasukkan sebagai "other information" ke dalam model Ohlson (1995). Hal ini sesuai dengan penelitian yang dilakukan oleh Vafei (2011) yang menyatakan bahwa pengungkapan modal intelektual dapat

mengurangi "information gap" antara perusahaan dan investor.

Hasil pengujian model 2 adalah untuk menguji determinan pengungkapan modal intelektual, dapat dilihat dalam tabel berikut :

Tabel 3. Ringkasan Hasil Determinan Pengungkapan Modal Intelektual

\begin{tabular}{|c|c|c|c|}
\hline Variabel Independen & Koefisien beta & t & Sig \\
\hline AGE & $-0,145$ & $-3,31$ & 0,001 \\
\hline AUDIT & 0.284 & 5,827 & 0.000 \\
\hline LEV & $-0,054$ & $-1,160$ & 0,247 \\
\hline MB & 0,141 & 3,030 & 0,003 \\
\hline PROF & $-0,079$ & $-1,792$ & 0,074 \\
\hline SIZE & 0,395 & 7,977 & 0,000 \\
\hline TYPE & 0,231 & 5,067 & 0,000 \\
\hline Sig. F & \multicolumn{3}{|c|}{$\mathbf{0 , 0 0 0}$} \\
\hline R Square & $\mathbf{0 , 3 7 9}$ \\
\hline Adj. R-Square & $\mathbf{0 , 3 6 5}$ \\
\hline
\end{tabular}

Variabel umur perusahaan memiliki nilai signifikansi sebesar 0,001 dan memiliki nilai beta $-0,145$. Nilai signifikansi tersebut dibawah tingkat signifikansi 0,05 yang berarti bahwa terdapat cukup bukti umur perusahaan berpengaruh negatif terhadap luas pengungkapan modal intelektual perusahaan. Pada pengujian dengan menggunakan uji signifikansi individual, ditemukan bahwa umur perusahaan memiliki pengaruh negative terhadap pengungkapan modal intelektual diperusahaan. Hal ini dapat diartikan bahwa perusahaan yang memiliki umur muda biasanya menggungkapkan modal intelektualnya lebih banyak daripada perusahaan yang berumur lebih tua. Hal ini diharapkan oleh perusahaan muda untuk dapat bersaing dengan kompetitor yang lebih dulu dipasar dan berusaha memberikan sinyal kepada investor untuk berinvestasi diperusahaannya. Perusahaan berumur lebih muda juga perlu untuk mengungkapkan lebih banyak untuk mengurangi skeptisme dan meningkatkan kepercayaan investor, karena perusahaan lebih muda dianggap memiliki resiko yang lebih tinggi. Hal tersebut sesuai dengan apa yang dijelaskan oleh Cormier et al. (2005)

Variabel kualitas audit memiliki nilai signifikansi sebesar 0,000 dan memiliki nilai beta 0,284 . Nilai signifikansi tersebut dibawah tingkat signifikansi 0,05 yang berarti bahwa terdapat cukup bukti bahwa kualitas audit berpengaruh terhadap 
luas pengungkapan modal intelektual perusahaan. Hasil penelitian ini sejalan dengan penelitian yang dilakukan Woodcock dan Whitting (2009). Hal tersebut mendukung teori keagenan yang menyatakan perusahaan berbiaya keagenan tinggi cenderung menggunakan jasa dari auditor yang terafiliasi dengan Big Four. KAP Big Four biasanya akan meminta kliennya untuk mengungkapkan informasi dalam laporan keuangan lebih banyak dan detail untuk menjaga reputasi dari KAP tersebut. Selain itu, besar dan diketahuinyakantor akuntan dapat memotivasi manajer untuk mengungkapkan lebih banyak informasi.

Variabel leverage memiliki nilai signifikansi sebesar 0,247 dan memiliki nilai beta-0,054. Nilai signifikansi tersebut diatas tingkat signifikansi 0,05 yang berarti bahwa leverage tidak berpengaruh terhadap luas pengungkapan modal intelektual perusahaan. Hal ini sejalan dengan penelitian yang dilakukan oleh Woodcock dan whiting (2009), Ferreira et al. (2012) dan Setianto (2014). Leverage tidak berpengaruh terhadap pengungkapan modal intelktual karena tujuan dari perusahaan adalah untuk memaksimalkan keuntungan pemegang saham yang dilakukan dengan cara meningkatkan laba perusahaan. Untuk tujuan tersebut, perusahaan akan berupaya untuk meningkatkan efisiensi biaya operasional guna meningkatkan laba. Agar laba yang dilaporkan tinggi maka manajer harus mengurangi biaya-biaya, termasuk pengungkapan modal intelektual.

Variabel nilai perusahaan memiliki nilai signifikansi sebesar 0,003 dan memiliki nilai beta 0,141 . Nilai signifikansi tersebut dibawah tingkat signifikansi 0,05 yang berarti bahwa terdapat cukup bukti nilai perusahaan berpengaruh positif terhadap luas pengungkapan modal intelektual perusahaan. Hasil dari penelitian ini menyimpulkan bahwa nilai perusahaan berpengaruh positif terhadap harga saham perusahaan. M/B ratio mengindikasikan perusahaan yang harga sahamnya sedang bertumbuh dan perusahaan akan berusaha untuk meningkatkan valuasi dari saham perusahaan mereka. Perusahaan yang memiliki market to book ratio yang tinggi berusaha untuk menjaga ekspektasi pasar untuk mejaga harga sahamnya, sehingga perusahaan yang memiliki $\mathrm{M} / \mathrm{B}$ ratio yang tinggi berusaha untuk memberikan informasi non- keuangan yang lebih untuk menjaga sinyal yang baik kepada investor dan menginformasikan keunggulan perusahaan tersebut.

Hasil selanjutnya menunjukkan bahwa profitabilitas tidak memiliki pengaruh terhadap pengungkapan modal intelektual. Variabel profitabilitas memiliki nilai signifikansi sebesar 0,074 dan memiliki nilai beta $-0,079$. Nilai 
signifikansi tersebut diatas tingkat signifikansi 0,05 yang berarti bahwa profitabilitas tidak memiliki pengaruh terhadap luas pengungkapan informasi modal intelektual perusahaan. Hasil ini konsisten dengan penelitian yang dilakuakan Ferreira et al. (2012) yang memberikan arti jika perusahaan tidak tertarik untuk memberikan sinyal melalui peningkatan luas pengungkapan modal intelektual untuk membedakan dengan perusahaan lain yang kurang menguntungkan. Hal ini dikarenakan hal tersebut tidak akan memberi manfaat bagi posisi dan kompensasi yang diperolehnya.

Selain itu, perusahaan yang mampu menghasilkan profit yang tinggi namun kurang tanggap terhadap masalah modal intelektual, hanya akan menganggap bahwa pengungkapan modal intelektual akan meningkatkan biaya sehingga perusahaan dapat kurang bersaing dengan perusahaan lain.

Variabel ukuran perusahaan memiliki nilai signifikansi sebesar 0,000 dan memiliki nilai beta 0,395 . Nilai signifikansi tersebut dibawah tingkat signifikansi 0,05 yang berarti bahwa terdapat cukup bukti ukuran perusahaan berpengaruh positif terhadap luas pengungkapan modal intelektual perusahaan. Hasil penelitian ini konsisten dengan dengan penelitian yang dilakukan oleh Puromosidhi (2006), Bruggen et al.,
(2009), dan Ferreira et al., (2012) Hasil penelitian ini berhasil mendukung teori keagenan yang menyatakan bahwa biaya keagenan bertambah seiring dengan bertambahnya modal eksternal yang cenderung lebih tinggi pada perusahaan yang lebih besar (Jensen dan Meckling, 1976). Sementara salah satu cara efektif yang dapat dilakukan untuk mengurangi asimetri informasi dan biaya keagenan adalah dengan melakukan pengungkapan sukarela. Dengan demikian, ukuran perusahaan dapat menjadi pendorong bagi perusahaan untuk melakukan pengungkapan modal intelektual.

Variabel tipe perusahaan memiliki nilai signifikansi sebesar 0,000 dan memiliki nilai beta 0,231 . Nilai signifikansi tersebut dibawah tingkat signifikansi 0,05 yang berarti bahwa terdapat cukup bukti tipe perusahaan berpengaruh positif terhadap luas pengungkapan modal intelektual perusahaan. Perusahaan dengan knowledge-intensive seperti perusahaan telekomunikasi, telnologi dan farmasi akan lebih berusaha untuk menunjukkan keunggulan kompetitif mereka untuk dapat menciptakan nilai dibanding dengan perusahaan tradisional seperti perkebunan, jasa konstruksi, semen, dll. Hal ini sejalan dengan penelitian yang dilakukan oleh Woodcock (2009) yang menunjukkan bahwa perusahaan yang beroperasi pada industri yang membutuhkan modal 
intelektual tinggi akan mengungkapkan modal intelektual lebih banyak.

\section{KESIMPULAN DAN SARAN}

\section{Kesimpulan}

Setelah melakukan perngujian terhadap model penelitian, ditemukan bukti bahwa atas hipotesis yang diajukan. Hasil Penelitian tersebut adalah sebagai berikut

Relevansi nilai dari informasi nonkeuangan berupa pengungkapan modal intelektual :

a. Pada perusahaan tradisional pengungkapan modal intelektual memiliki pengaruh positif terhadap harga saham perusahaan

b. Pada perusahaan nontradisional pengungkapan modal intelektual tidak memiliki pengaruh terhadap harga saham perusahaan

c. Menambahkan pengungkapan modal intelektual sebagai "informasi lain" dalam model Ohlson (1995) meningkatkan kekuatan penjelas nilai pasarnya di industri tradisional

d. Menambahkan pengungkapan modal intelektual sebagai "informasi lain” dalam model Ohlson (1995) meningkatkan kekuatan penjelas nilai pasarnya di industri nontradisional
Determinan pengungkapan modal intelektual :

a. Umur perusahaan memiliki pengaruh negatif terhadap luas pengungkapan modal intelektual

b. Kualitas audit memiliki pengaruh positif terhadap luas pengungkapan modal intelektual

c. Leverage tidak memiliki pengaruh terhadap luas pengungkapan modal intelektual

d. Nilai perusahaan memiliki pengaruh positif terhadap luas pengungkapan modal intelektual

e. Profitabilitas tidak memiliki pengaruh terhadap luas pengungkapan modal intelektual

f. Ukuran perusahaan memiliki pengaruh postitif terhadap luas pengungkapan modal intelektual

g. Tipe industri memiliki pengaruh positif terhadap luas pengungkapan modal intelektual

\section{Saran}

Berdasarkan kesimpulan yang telah diperoleh dari hasil penelitian, beberapa saran diajukan antara lain:

a. Bagi peneliti selanjutnya, diharapkan menambah jumlah tahun dan juga jumlah sampel dalam pengamatan, hal ini untuk melihat konsistensi hasil penelitian. Dan juga pada penelitian selanjutnya 
diharapkan untuk meneliti pengungkapan modal intelektual dari website perusahaan, press releases, dan prospectus perusahaan, karena dalam penilitian ini memiliki keterbatasan hanya menangkap informasi dari laporan tahunan perusahaan.

b. Bagi perusahaan, sebaiknya dapat meningkatkan luas pengungkapan modal intelektual karena informasi tersebut dapat memeberikan sinyal kepada investor dalam mengambil keputusan.

c. Bagi regulator, Hasil penelitian memperlihatkan bahwa kurangnya inisiatif perusahaan dalam mengungkapkan informasi tentang modal intelektual. Oleh karena itu, disarankan agar regulator dapat membuat peraturan yang dapat meningkatkan jumlah informasi pengungkapan intelektual sehingga dapat bermanfaat bagi para pengguna laporan keuangan.

\section{DAFTAR PUSTAKA}

Abdolmohammadi, M.J. 2005, "Intellectual capital disclosure and market capitalization." Journal of Intellectual Capital. Vol. 6 No. 3. Pp. 397-416.

Alfraih, Mishari, 2018, "Intellectual capital reporting and its relation to market and financial performance", International Journal of Ethics and Systems, https://doi.org/10.1108/IJOES-022017-0034

Alsaeed, K., 2006, "The association between firm- specific characteristics and disclosure: the case of Saudi Arabia”, Managerial Auditing Journal, Vol. 21 No. 5, pp. 476-496.

Amir, E. and Lev, B. 1996, "Valuerelevance of nonfinancial information: the wireless communications industry", Journal of Accounting and Economics, Vol. 22 Nos 1/3, pp. 3-30.

Baker, Malcolm, and Jeffrey Wurgler, 2002," Market Timing and Capital Structure." Journal of Finance. Vol.57, pp.1-32.

Ball, R dan P Brown 1968, “An Empirical Evalution of Accounting Income Numbers." Journal of Accounting Research. Vol.6, Hal. 159-178.

Barako, D.G., Hancock, P. and Iznan, H.Y. 2006, "Factors influencing voluntary corporate disclosure by Kenyan companies", Corporate Governance - An International Review, Vol. 14 No. 2, pp. 107-125.

Blanco, B., Garcia Lara, J.M. and Tribo, J.A. 2015, "Segment disclosure and cost of capital", Journal of Business 
Finance \& Accounting, Vol. 42 Nos 3/4, pp. 367-411.

Brown, S. and Hillegeist, S.A. 2007, "How disclosure quality affects the level of information asymmetry", Review of Accounting Studies, Vol. 12 Nos 2/3, pp. 443-477.

Bruggen, et. al. 2009, "Determinants Of Intellectual Capital Disclosure: Evidance From Australia.” Management Decision.Vol. 47 No 2,2009.pp. 233-234.

Bukh, c. Nielsen, P. Gormsen, and J. Mouritsen. 2003, "Commentary, the relevance of intellectual capital disclosure: a paradox?" Accounting, Auditing \& Accountability Journal. Vol. 16 No. 1. Pp. 49-56.

Bukh, P. N., Nielsen, C., Gormsen, P., and Mauritsen, J. 2005, "Disclosure of Information on Intellectual Capital in Danish IPO Prospectus." Accounting, Auditing \& Accountability Journal, 18(2), 713732

Bozzolan, S., Francesco Favotto and Federica Ricceri. 2003, "Italian annual intellectual capital disclosures: An empirical analysis", Accounting, Auditing \& Accountability Journal, Vol. 4. No. 4, pp. 543-558.

Cormier, D., Ledoux, M. and Magnan, M., 2009, "The Use of Web Sites As a
Disclosure Platform For Corporate Performance", International Journal of Accounting Information Systems, Vol. 10 No. 1, pp. 1-24.

Eccles, R.G., Serafeim, G. and Krzus, M.P. 2011, "Market interest in nonfinancial information", Journal of Applied Corporate Finance, Vol. 23 No. 4, pp. 113-127.

Ferreira, A. L., Branco., M. C., and Moreira, J. A. 2012, "Factors Influencing Intellectual Capital Disclosure by Portuguese Companies", International Journal of Accounting dan Financial Reporting, Vol. 2(2), hal. 278.

Firer, S. and Williams, S.M. 2003, "Intellectual capital and traditional measures of corporate performance", Journal of Intellectual Capital, Vol. 4 No.3, p. 348.

Francis, J. and K. Schipper. 1999, "Have Financial Statements Lost Their Relevance ?" Journal of Accounting Research, 37(2): 319-352

Garanina, T. and J. Dumay. 2017, "ForwardLooking Intellectual Capital Disclosure in IPOs Implications for Intellectual Capital and Integrated Reporting." Journal of Intellectual Capital, 18 (1), 128-148. 
Guthrie, J., R. Petty, \& F. Ricceri. 2006, "The Voluntary Reporting of Intellectual Capital." Journal of Intellectual Capital, 7 (2) : 254-271

Healy, P. and Palepu, K., 2001, "Information asymmetry, corporate disclosure, and the capital markets: a review of the empirical disclosure literature", Journal of Accounting and Economics, Vol. 31 Nos 1/3, pp. 405-440.

IASB- International Accounting Standart Board, 2010. 'The Conceptual Framework for Financial Reporting." International Financial Reporting Standarts (September): 131

Jensen, Michael C \& Meckling, Wiliam H. 1976, "Theory of the Firm: Managerial Behavior, Agency Cost and Ownership Structure." Journal of Financial Economics. 3 (4): 305360.

Lev, B. and Zarowin, P. 1999, "The boundaries of financial reporting and how to extend them", Journal of Accounting Research, Vol. 37 No. 2, pp. 353-385.

Ohlson, J.A. 1995, "Earnings, book values, and dividends in equity valuation", Contemporary Accounting Research, Vol. 11 No. 2, pp. 661-687.
Ohlson, J.A. 2001, "Earnings, book values, and dividends in equity valuation: an empirical perspective", Contemporary Accounting Research, Vol. 18 No. 1, pp. 107120.

Rachmawati, Dyna. 2018, "Relevansi Nilai Pengungkapan Modal Intelektual Secara Voluntary dan Involuntary." Jurnal Akuntansi dan Keuangan Indonesia, Desember 2018, Vol. 15, No. 2, hal 121-137

Setianto. A. Putra., Purwanto. Agus. 2014, “Analisis Faktor-Faktor yang Mempengaruhi Pengungkapan Modal Intelektual (Studi Empiris pada Perusahaan yang Terdaftar di 'Indeks Kompas 100' Tahun 20102012)." Diponegoro Journal of Accounting. Volume 3, Nomor 4, Tahun 2014, Halaman 1-15

Vafei, A., Taylor, D., and Ahmed, K. 2011, "The value relevance of intellectual capital disclosures." Journal of Intellectual Capital, 12(3), 407-429

Widowati, S., dan D. Rachmawati. 2017, "Analisis Pengaruh Arus Kas Operasi, Laba, Kepuasan Karyawan, dan Kepuasan Pelanggan untuk Memprediksikan Arus Kas Operasi Masa Depan.” Tesis. Fakultas Bisnis Universitas Katolik Widya Mandala Surabaya.

http://repository.wima.ac.id 
JAFTA - Vol 2 Nomor 1, Oktober (2020)

Woodcock, James. Dan Rosalind. H, Whiting.2009, “Intellectual Capital Disclosure by Australian Companies." Australian Accounting Jurnal. Vol 2,No 2:211-242. 